\title{
A Study To Assess The Knowledge Regarding The Need Of Forensic Nursing In Emergency Department Among The Staff Nurses In A Selected Hospital At Visakhapatnam, Andhra Pradesh
}

\author{
S.V.L. Padmakumari \\ Medical Surgical Nursing, Katuri College Of Nursing, Guntur. \\ DOI: 10.29322/IJSRP.12.01.2022.p12128 \\ http://dx.doi.org/10.29322/IJSRP.12.01.2022.p12128
}

\begin{abstract}
BACKGROUND OF THE STUDY
Forensic nursing is an emergent specialty area of practice that has undergone substantive role development in recent years ${ }^{3}$. Forensic nurses have not only begun to write about the challenging and distinctive nature of their practice and their unique practice arrangements, but have commenced a concerted call to action for greater recognition within the nursing profession and correction and criminal justice system ${ }^{5}$. An increasing demand for forensic nursing skills in a range of community and hospital based clinical settings. The problematic nature of caring for forensic clients in both correctional and less restrictive contexts of care remains a salient feature of forensic nurses' accounts of their practice. The present study was carried out to determine the knowledge of staff nurses regarding the need of forensic nursing in emergency department ${ }^{7}$.
\end{abstract}

\section{OBJECTIVES OF THE STUDY:}

1) To assess the socio demographic variables of the staff nurses.

2) To assess the knowledge of staff nurses regarding the need of forensic nursing in emergency department.

3) To associate knowledge of staff nurses with selected demographic variables.

\section{METHODS}

A descriptive study was undertaken to assess the knowledge of the staff nurses in a selected hospital Visakhapatnam.The population for the present study consisted of all the staff nurses of Government Hospital Vishakhapatnam . Purposive sampling technique was used to select 60 staff nurses who were present at the time of data collection. The data was collected in the month of April 2011 from 60 samples.

\section{RESULTS:}

$>$ The incidence was that majority (39\%) of staff nurses were in the age group of 20-30 years and minimum of $23 \%$ (14) were in the age group of $41-50$ years, were participated in the study.

$>$ The knowledge level of staff nurses were $53.3 \%$ had inadequate knowledge, $46.6 \%$ were having moderate knowledge and none of the staff nurses had adequate knowledge on forensic nursing.
$>$ There was no significant association between the knowledge levels and selected demographic variables.

\section{INTERPRETATION AND CONCLUSION:}

The study findings show that the knowledge levels of the staff nurses were inadequate regarding the forensic nursing. Awareness regarding the forensic nursing will help in improving their knowledge and also it will extend the role of nursing with a new trend.

Index Terms- Knowledge , Staff Nurses, Forensic Nursing, Emergency Department.

\section{INTRODUCTION}

T fou're a fan of mystery novels and true-crime dramas, this lexciting career that combines nursing with detective work and criminal law is well worth investigating"

\section{Susan Wessling}

Nursing is one of the noblest professions in the world, which reminds us of Florence Nightingale. In the healthcare sector, nurses play a leading role from the general ward to the operating theatre and form an integral part. The largest group of workers in the health sector are nurses and nursing assistants. With the expansion of the health industry, the demand for nurses is also increasing making the career very attractive with wide range and opportunities. As evidence based discipline devoted to the betterment of humanity, nursing has developed into an art as well as science ${ }^{1 .}$

Nursing duties are manifold and cover a wide range of functions and responsibilities that depends with the level of qualification and the working environment. At the initial era, nurses were only required for the bedside care of patients, while presently they are managing special group of people like psychiatric, pediatric, intensive care patients etc which require specialized skills.. The nurse also needs to work at different places in hospitals such outpatient departments, emergency room, medical and surgical wards, Intensive care units, Operation 
Theater, radiotherapy, chemotherapy and even in community and home set up also

The emergency Department( ED) is an institution of its own that truly has an open door policy. It is accessible 24 hours a day, seven days a week to those in need. Medical professionals one available to assist individuals who have been involved in life threatening trauma ${ }^{3}$. Drawing public attention and awareness towards traumatic casualties is important to prevent unnatural deaths, this possibly could reduce incidence of such cases.

Forensic nursing bridges the gap between health care and law enforcement. It's the application of the science and art of nursing to criminal and civil investigations and legal matters. Forensic nurses provide care to victims and trauma or death due to traumatic events or criminal acts. Forensic nurses not only assist their patients' physical and emotional recoveries, but they are also trained to recognize and collect evidence while treating a patient's wounds. This is an extremely delicate and crucial aspect to their job $^{5}$.

The term "forensic nursing" was officially coined in 1992, during the first national convention for sexual assault nurses that led to the founding of the International Association of Forensic Nurses (IAFN).Virginia Lynch from the USA's considered as a pioneer of forensic nursing. Lynch did not invent it, but she gave it a name long before the IAFN. In 1995, the American Nursing Association recognized it as a specialty (McPeck, 2002). The theoretical model of forensic nursing evolved from the role of the police surgeon or police medical officer of the United Kingdom and European countries, Nurses were hired by the police department and were responsible for facilitating the management of the crime victim from the scene of the incident through the legal process $^{6}$

Forensic nursing has scope in various fields. Forensic nurses are first of all needed in the emergency room of a hospital. In the confusion and chaos of an emergency room often valuable evidence is lost. If the critically injured patient was the victim of an accident or human violence or other criminal acts are admitted to a hospital where generally evidence against the criminal is overlooked and hence lost. The presence of a forensic nurse ensures that this does not happen. A Forensic nurse is fully trained to look into every aspect of the case and collect evidence. This way the criminal does not easily escape from the law. There is a desperate need to check the fast growing crime rates in our society which makes forensic nursing a necessity ${ }^{8}$

Nursing in forensic is a wide field and has specializations for different works. Some of these are SANE (Sexual Assault Nurse Examiner), Emergency Room Nursing, Medical Legal Consultant, Medical Examiner's office, Medico-legal death investigator, Law enforcement teams, Evidence collection trainer and so on. Many people are worried that forensic nursing would require them to be surrounded by the dead and the criminals all the time. This is not true. You can choose your area of specialization and work within that area. So if working with the dead bothers you could choose other fields of specialization ${ }^{10}$.

\section{NEED FOR THE STUDY}

Nursing, in it itself, is a very difficult profession. There is so much medical terminology to understand, so many techniques to master, and beyond that, a great deal doctors and other medical professionals with a variety of personalities and temperaments to work alongside. Bringing that into an emergency room, which is usually in a state of jumble, and things can really be crazy ${ }^{1}$. Nurses are working in emergency room have an additionally responsibility for recognizing when a potential crime has taken place and following evidence collection and other procedures that need to handle in right away in order for justice to eventually be served. Nursing has a varied field in the overall areas of healthcare and not all nurses simply works in hospitals, clinics, or nursing homes caring for patients. Forensic nurses, for example, combine nursing skills with the fields of detective work and criminal law by undergoing specialized training and gaining specific experience in forensic evidence collection, procedures in dealing with criminals, legal testimony expertise, and more ${ }^{15}$

In reality, most people who come into the emergency room don't know that they are in need of a forensic nurse, usually they are in too painful situation and events that preceded them. To meet traumatic situations head on and begin to understand the causes of them and get down to the bottom of what truly happened ${ }^{9}$. The report by World Health Organization shows that more than a million people lose their lives annually, and some suffer non-fatal injury due to various types of violence; e.g. self inflicted, interpersonal and collective violence (Krug, Dahlberg, Mercy, Zwi and Lozano, 2002). Violence is one among the leading cause of death worldwide between the age group of 15-44 years and Road traffic collisions represent the largest contribution to the problem of injury in the India. During 1999, nearly 41000 people died and 3.3 million were injured from road traffic collisions ${ }^{16}$.

The researcher reports on statistics for the year 2001 and 2002 were as follows: 21400 cases killed due to trauma and 540 000 cases of rape were reported. The National Injury Mortality Surveillance System (NIMSS) annual report for the year 2002 reveals that $60 \%$ of pedestrians killed in road traffic collisions were under the influence of alcohol. Further $45.4 \%$ of homicide cases were reported and the leading cause of homicide was due to gunshots and sharp force injury, such as stab wounds Matzopoulos, Seedat, Marais and van Niekerk ${ }^{17}$.

The incidence of emergency room in King George Hospital Visakhapatnam is total number of Medico Legal Cases per day are 32-35 cases. Among them poison cases are 2-3 per day, assault cases are 6-8 per day, child abuse cases are 2-3 cases per week, sexual assault 8-10 per month and trauma or accident cases are 2022 cases.

The victims of violence and its associated trauma enter the emergency departments on a 24 -hour basis. The emergency nurses are exposed to these victims, some of whom are the perpetrators. When a victim arrives in the emergency department saving his/her life is a priority and what may be forgotten is the importance of proper handling of the victim's items that might contain forensic evidence and can be of value later.

Nurses are more readily available than doctors to preserve evidence. They provide services in remote and rural communities and have displayed more empathy towards survivors of abuse than doctors. Thus nurses can empower the victims of abuse and improve the rate of reporting cases. Steps should be undertaken to have forensic nursing recognized as a specialty by the Indian Nursing Council. It is also important to recognize the forensic 
nursing as a means of improving health care delivery and the administration of justice ${ }^{17}$.

The forensic physician and clinical forensic nurse are needed to bridge the gap between the criminal justice and health care systems in the management of forensic patients, because they handle the property of and information about the patient that may be useful later in a forensic investigation A senior district surgeon, who, with the aid of a United States Forensic Nursing Programme, instituted a Sexual Assault Nursing Examiner (SANE) course, initiated the introduction of forensic nursing into the history of nursing. Twenty-four nurses were trained in Kimberley in 2000, and a group of 40 nurses were trained in KwaZulu-Natal in 2001 as a $\mathrm{SANE}^{12}$.

Development of forensic nursing in India started step by step. Many new subspecialties are developing in the various scientific fields. Their introduction and development usually face same kind of problems. Same is true about forensic nursing. First it was started as specialty in USA and then it traveled to various parts of the world like Sweden, South Africa, Japan, Singapore and Malaysia. In India Virginia Lynch visited in Dec.2002. Introductory seminar was held in the Govt. Medical College, Patiala where doctors, nurses, Judges, advocates and police officials gathered together and they were introduced to the concept of forensic nursing and its utility to the investigating officers and the judiciary ${ }^{18}$.

Forensic nursing was accepted in most part of the country. With the kind permission of Dr. Ravinder Singh who taught forensic nursing at Govt. Medical College, Patiala. They started attending theory classes. They were also demonstrated postmortem examination, examination of injured persons as well as who were sexually assaulted. of Dr. Ravinder Singh also demonstrated cases of poisoning. In all these cases special stress was laid on collection of samples, their preservation, packing and dispatch to the forensic science laboratory ${ }^{18}$.

In India, since forensic nursing is still in its infancy stage, the role behavior and the role expectations of forensic nursing in emergency departments is not clear. Furthermore, nurses have previously been a largely untapped resource in collaborative partnerships between health and justice systems when managing the forensic care component of patients, who are either accused or are the victims of criminal liability related injuries. Without a clearly defined role and set of skills, it is difficult to ascertain the education and training requirements of forensic nursing ${ }^{30}$.

Emergency nurses in India are facing new challenges in acquiring the skills and knowledge to effectively care for crime victims. It is becoming extremely important for the nurses to carefully handle the forensic evidences for proper justice. As a researcher I felt that all the nurses should be aware about the forensic sciences and explore forensic nursing knowledge as a specialty area of study, influencing its educational development. The keen interest of researcher, increased incidence of medicolegal cases and crucial role of emergency nurse and need for awareness on forensic nursing has motivated the researcher to understand a study to assess the knowledge regarding the need of forensic nursing in emergency department among staff nurses in a selected hospital at Vishakhapatnam.

\section{METHODOLOGY:}

\section{RESEARCH APPROACH:}

The selection of research approach is the basic procedure for conducting research enquiry. In the view of nature of the problem selected and objectives to be accomplished, a descriptive approach was considered appropriate for the present study.

\section{STUDY DESIGN}

A descriptive survey design was planned to assess the knowledge regarding the need of forensic nursing in emergency department among the staff. In this study all the staff nurses from different departments were surveyed and responses were elicited. The schematic representation of the research design in Fig: 2

\section{VARIABLES:}

The variables identified in this study are were age, professional education, years of experience in emergency department, sources of information, Staff nurses, knowledge level, need of forensic nursing.

\section{SETTING OF THE STUDY:}

The study was conducted in King George Hospital, Visakhapatnam, Andhra Pradesh. The hospital served the needs of north coastal Andhra Pradesh and adjacent Orissa for more than 150 years. It was started in 1845 and it is 1035 beaded. All the Emergency, Out-Patient, In-Patient and Community Services are well established. Around 1500 staff nurses are working in this hospital and they work the shift of 8hours per day.

\section{POPULATION:}

In this present study, population consists of staff nurses of King George Hospital, Visakhapatnam Andhra Pradesh.

\section{SAMPLE:}

In this Study sample consists of 60 staff nurse working in King George Hospital, Visakhapatnam, and Andhra Pradesh.

\section{Sampling Technique:}

In this study Purposive sampling techniques was adapted .It is one of the non-probability sampling and is sometimes referred as "judgmental or theoretical" sampling which involves the purposeful selection by the investigator of certain subject or elements to include in the study.

\section{CRITERIA FOR THE SAMPLE SELECTION INCLUSION CRITERIA:}

In this study inclusion criteria are:

Staff nurses who are :

$>$ working at Government Hospital, Visakhapatnam.

$>$ Staff nurses who are available at the time of data collection

$>$ Staff nurses who are willing to participate in the study.

\section{EXCLUSION CRITERIA:}

In this study exclusion criteria are: 
Staff nurses who are:

$>$ Not willing to participate in the study

$>$ Not present during study.

\section{DATA COLLECTION INSTRUMENT:}

In the present study demographic data and self administered structured questionnaire was used as tool for data collection.

\section{DEVELOPMENT OF THE TOOL:}

An exclusive search of literature was made for the purpose of developing appropriate tool for Knowledge regarding the need of forensic nursing in emergency department among the staff nurses An structured questionnaire was developed with the help of related literature from various text books, journals, and discussion with experts in the fields of Medical Surgical Nursing, Community health nursing and guide to assess the knowledge of health care workers regarding the need of forensic nursing in emergency department.

\section{BLUE PRINT:}

The blue print was developed based on the obtained information from the review of literature and after discussion with the guide and experts of the other department. It depicted the distribution of items according to the area under the main domains: Emergency department (3items/ 6.6\%), forensic nursing(6 items/
$13.3 \%$ ), Evidence collection (19items/ 42.2\%), Storage (9 items/ 20\%), (8 items/ 17.7\%) Documentation

\section{DESCRIPTION OF THE TOOL:}

In order to assess Knowledge of staff regarding the need of forensic nursing in emergency department .Structured questionnaire is developed by the investigator.

The data collection tool has been divided into 2 sections.

Sec- A:

It consists of selected demographic variables such as age, sex, professional education, years of experience in emergency department, source of information.

\section{Sec- B:}

It consists of structured questionnaire containing 45 multiple choice questions to choice questions it includes

Section I-

Section II-

Questions related to emergency department

Section IIIevidences

Section IV- $\quad$ Storage and

Section V- Documentation. 
SCHEMATIC REPRESENTATIONOF THE STUDY

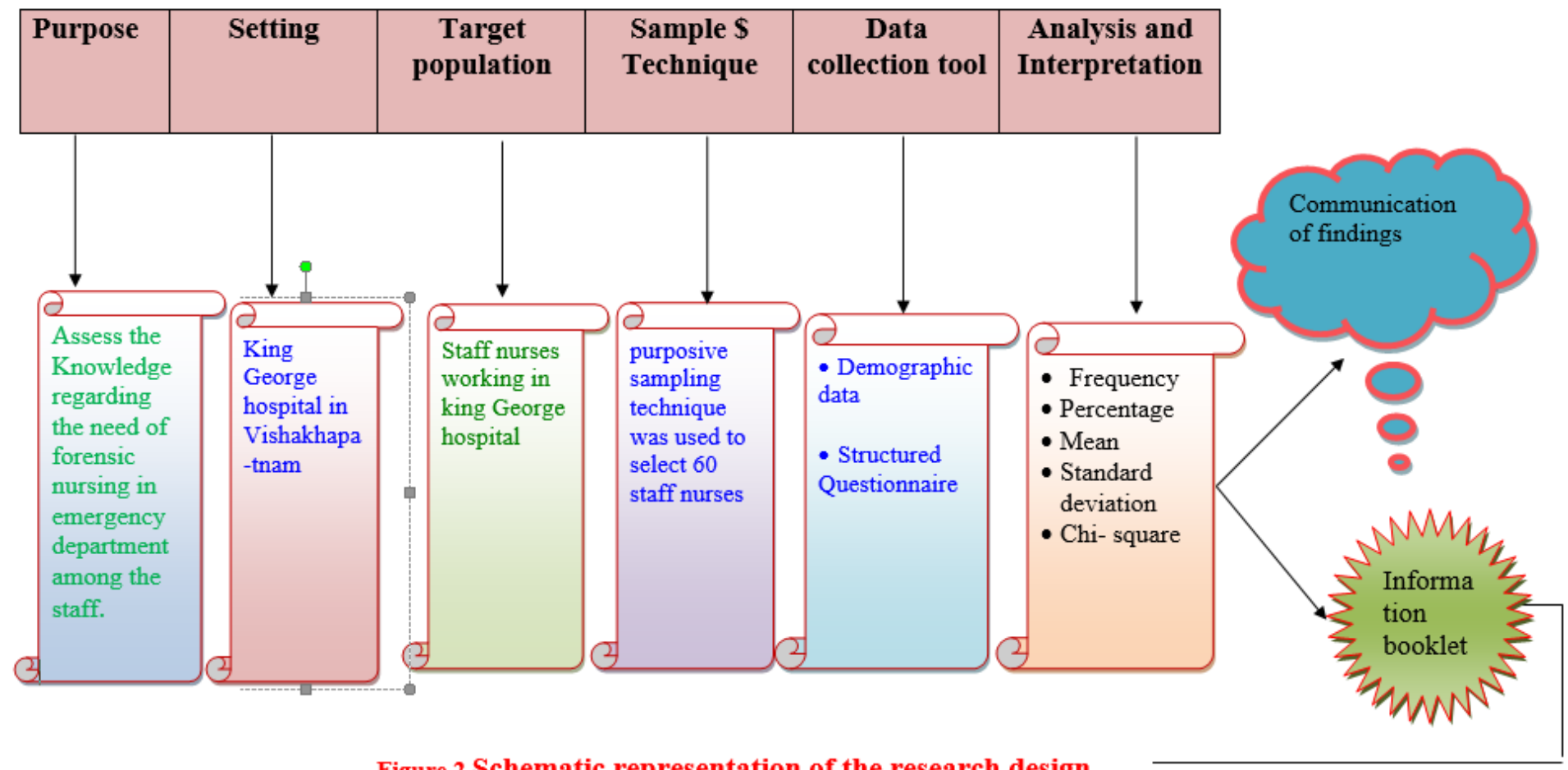

Figure 2 Schematic representation of the research design 


\section{VALIDITY}

Content validity of the tool was established by the 10 experts of nursing and medicine. Among the experts, one were the emergency physician, one were forensic doctor and seven were nursing specialist in medical and surgical field. Modifications were made based on the suggestions and comments given by experts and the guide.

\section{RELIABILITY :}

Reliability of research instrument is defined as the extent to which the instrument yields the same result on repeated measure. It is then concerned with consistency, accuracy, recession, stability, equivalence and homogeneity ${ }^{48}$.

Section B: The reliability of the structures questionnaire was computed using split- half method, for the internal consistency using Spearman's correlation coefficient.

$$
\begin{gathered}
r=1-\frac{6 x \sum \mathrm{d}^{2}+T x+T y}{n\left(n^{2}-1\right)} \\
r=0.81
\end{gathered}
$$

The reliability of the entire tool was estimated using spearman's prophecy formula;

$$
\hat{\mathrm{r}}=\begin{gathered}
2 \mathrm{r} \\
---- \\
1+\mathrm{r} \\
\mathrm{r}=0.89
\end{gathered}
$$

The coefficient of correlation $r$ ' is 0.89 hence the modified disability scale is found to be highly reliable.

\section{PILOT STUDY:}

Pilot study was conducted in the Government Hospital Vishakhapatnam between $15^{\text {th }}$ March 2011 to 25March 2011on 10 staff nurses. Formal administrative permission was obtained from the Nursing Superintendent of Government Hospital Vishakhapatnam and pilot study was conducted. The tool was administered to 10 staff nurses. The tool was found to be feasible and practicable. The subjects took 30 minutes to complete the proforma. Data analysis was done using descriptive and inferential statistics. The result revealed that the obtained that the objective of the study could be fulfilled. Based on this information the investigator was permitted by the guide to proceed with the actual data collection for the main study.

\section{DATA COLLECTION METHOD:}

Formal administrative permission was obtained from the Nursing Superintendent of King George Hospital Vishakhapatnam to collect the data. The data was collected from $15^{\text {th }}$ April 2011 to $14^{\text {th }}$ May 2011. Based on the inclusion criteria 60 samples were selected for the study. The purpose of the study was explained to the employee, confidentiality was assured to all the subjects and informed consent was obtained. The tool was administered to the staff nurses. The average time taken to answer the questionnaire ranged from 30-35 minutes. The master sheet was prepared for the data obtained from the samples.

\section{PLAN OF DATA ANALYSIS:}

The data obtained are analyzed in terms of the objectives of the study using descriptive inferential statistics.

The data collected during the actual study was planned to analyze with the help of descriptive and inferential statistics based on the objective as follows:

\section{DESCRIPTIVE ANALYSIS:}

- Frequency and percentage to describe the demographic data of staff nurses.

- Frequency and percentage to assess the level of knowledge among the staff nurses.

\section{INFERENTIAL ANALYSIS:}

- Chi square test to determine the association between knowledge level and selected demographic variables.

\section{SUMMARY:}

This chapter deal with the research approach, research design, description of the variables, setting of the study, population, sample and sampling technique, criteria for sample selection, description of sample characteristics, method of data collection, development and description of the tool, validity, reliability, pilot study, technique of data collection and the plan of data analysis.

\section{ANALYSIS AND INTERPRETATION RESULTS:}

$>$ The incidence was that majority (39\%) of staff nurses were in the age group of 20-30 years and minimum of $23 \%$ (14) were in the age group of 41-50 years, were participated in the study.

$>$ The knowledge level of staff nurses were 53.3\% had inadequate knowledge, $46.6 \%$ were having moderate knowledge and none of the staff nurses had adequate knowledge on forensic nursing.

$>$ There was no significant association between the knowledge levels and selected demographic variables.

\section{INTERPRETATION AND CONCLUSION:}

The study findings show that the knowledge levels of the staff nurses were inadequate regarding the forensic nursing. Awareness regarding the forensic nursing will help in improving their knowledge and also it will extend the role of nursing with a new trend. 
Table- 1 Knowledge Levels Of Staff Nurses

\begin{tabular}{|l|l|l|l|}
\hline SL.NO & Level of knowledge & Frequency (f) & Percentage (\%) \\
\hline 1 & Inadequate & 32 & $53.3 \%$ \\
\hline 2 & Moderate & 28 & $46.6 \%$ \\
\hline 3 & Adequate & - & - \\
\hline
\end{tabular}

TABLE- 2 Association between knowledge levels of staff nurses with selected demographic data such as Age and Professional Education

\begin{tabular}{|l|l|l|l|l|l|l|l|l|l|}
\hline SNO & VARIABLES & \multicolumn{2}{l|}{ INADEQUATE } & \multicolumn{2}{l|}{ MODERATE } & df & $\begin{array}{l}\text { Table } \\
\text { Value }\end{array}$ & $\begin{array}{l}\text { Chi- } \\
\text { square }\end{array}$ & significant \\
\hline & & $\mathbf{n}$ & $\mathbf{\%}$ & $\mathbf{n}$ & $\mathbf{\%}$ & & & & \\
\hline 1 & AGE & & & & & & & & \\
\hline & $20-30$ & 11 & 18.3 & 12 & 20 & & & & \multirow{2}{*}{ NS } \\
\hline & $30-40$ & 10 & 16.6 & 13 & 21.6 & 2 & 5.99 & 3.009 & \\
\hline & $40-50$ & 5 & 8.33 & 9 & 15 & & & & \\
\hline 2 & Professional education & & & & & & & & \multirow{2}{*}{ NS } \\
\hline & GNM & 17 & 28.3 & 17 & 28.3 & & & & \\
\hline & BSc(N) & 6 & 10 & 7 & 11.66 & 2 & 5.99 & 0.071 & \\
\hline
\end{tabular}

Table - 3 Association between knowledge levels of staff nurses with selected demographic data such as years of experience and source of information

\begin{tabular}{|l|l|l|l|l|l|l|l|l|l|}
\hline SNO & VARIABLES & \multicolumn{2}{l|}{ INADEQUATE } & \multicolumn{2}{l|}{ MODERATE } & df & $\begin{array}{l}\text { Table } \\
\text { Value }\end{array}$ & $\begin{array}{l}\text { Chi- } \\
\text { square }\end{array}$ & significant \\
\hline 1 & $\begin{array}{l}\text { Years of Experience in } \\
\text { Emergency Room }\end{array}$ & $\mathbf{n}$ & $\%$ & $\mathbf{n}$ & $\%$ & & & \multirow{2}{*}{ NS } \\
\hline & 1 to 5 & 4 & 6.66 & 1 & 1.66 & & & & \\
\hline & 6 to 10 & 12 & 20 & 6 & 10 & 3 & 7.82 & 3.2112 \\
\hline & 11 to 15 & 12 & 20 & 7 & 11.66 & & & & \\
\hline & 16 to 20 & 10 & 16.6 & 8 & 13.33 & & & & \multirow{2}{*}{ NS } \\
\hline & Source of information & & & & & & & & \\
\hline & Mass Media & 12 & 20 & 14 & 23.33 & & & & \\
\hline & Experience & 15 & 25 & 8 & 13.33 & 2 & 5.99 & 2.893 \\
\end{tabular}

\section{DISCUSSION}

The research findings are discussed in relation to similar studies conducted by other researcher. The present study has been conducted to assess the knowledge of staff nurses regarding the need of forensic nursing in emergency department .The data was collected from 60 respondents, analyzed by using descriptive and inferential statistics and presented in the form of tables and graphs.
Chi- square was applies to find out the association between knowledge level and demographic variables.

The findings of the study has been organized and discussed under the following sections:

Section I: $\quad$ Selected demographic variables of staff nurses. Section II: $\quad$ knowledge levels of staff nurses

Section III: Distribution of knowledge level of subject according to demographic data. 


\section{Section I: $\quad$ Selected demographic variables of staff nurses.}

It was found that majority $(39 \%)$ of staff nurses were in the age group of 20 -30year were as $38 \%$ were in the age group of $31-40 y r$ and $23.3 \%$ of them belongs to $41-50 y e a r$. These findings were supported by the study conducted on forensic nursing investigating carrier potential through postal questionnaire survey in 2008 by Anne Wolbert Burger, which showed that majority of the subject were at the age group of 20-30year.

It is evident from the present study findings that majority $(56.6 \%)$ of the staff nurses had GNM qualification where as $21.6 \%$ were $\operatorname{Bsc}(\mathrm{N})$ and $\mathrm{PC} \operatorname{Bsc}(\mathrm{N})$ qualification had participated in the study. These findings are in consistent with other study finding that $50 \%$ were GNM and $20 \%$ were $\mathrm{BSC}(\mathrm{N})$ conducted in 2002 by Nomusa NT.Abdool in a forensic nursing role in Emegency Room.

Percentage distribution of staff nurses based on the year of experience showed that majority (31\%) had 11-15year experienced and 30\% had 6-10year and 16 -20year of experienced. Similar findings are noted in a study experience conducted by Heneline and craft 2003 which reveals that majority ( $35 \%$ ) had $11-15$ years experience where as $30 \%$ had 610 years of experience.

Percentage distribution of staff nurses according to source of information regarding forensic nursing ,In this study majority $(43.3 \%)$ receive information through mass media and only $18.3 \%$ through self reading. These finding is in conformity with other study finding conducted in 2004 by Rooms that showed that majority $(50 \%$ )of the health care workers gained knowledge through mass media and 30\% gained knowledge through their experience.

\section{Section II: percentage distribution of level of knowledge of health care workers.}

In this section II the level of knowledge of the staff nurses were analyzed. It is revealed that majority $(53.3 \%)$ of staff nurses had inadequate knowledge, whereas $46.6 \%$ had moderate knowledge and none of them had adequate knowledge on need of forensic nursing in emergency department. Which depicts strong need to create awareness among the expanded role. Similar results were noticed in a study conducted by Johnson in 2005, which revealed that staff nurses had inadequate knowledge regarding forensic nursing.

\section{Section III: Association between knowledge levels of staff nurses with selected demographic data}

The result of the study revealed that there was no association between level of knowledge and selected demographic variable as the obtained chi-square value is less than the table value. These findings are similar with the findings of another study conducted by Dian William -2006 which shows that no significant association between the level of knowledge and age $\left(\mathrm{x}^{2}=1.43\right.$ $\mathrm{p}=3.843)$ and source of income $\left(\mathrm{x}^{2}=2.65, \mathrm{p}=5.99\right)$ by in providing quality care to sexual assault survivor education. Whereas other study conducted by Peternelji- Taylor showed an contradictory results stating there was on association between the knowledge level and professional education $\left(\mathrm{x}^{2}=4.46 \mathrm{p}=3.843\right)$ and years of experience $\left(\mathrm{x}^{2}=5.46 \mathrm{p}=3.843\right)$ as the chi-square value is greater than the $\mathrm{p}$ value.

This chapter deals the discussion of the study findings in relation to the other studies conducted by the researcher. It is evident by the discussion that staff nurses working in different areas with years of experience are having inadequate knowledge regarding the forensic nursing.

\section{CONCLUSION}

Forensic nursing is an emergent specialty area of practice that has undergone substantive role development in recent years. Forensic nurses have not only begun to write about the challenging and distinctive nature of their practice and their unique practice arrangements, but have commenced a concerted call to action for greater recognition within the nursing profession and correction and criminal justice system. An increasing demand for forensic nursing skills in a range of community and hospital based clinical settings. The problematic nature of caring for forensic clients in both correctional and less restrictive contexts of care remains a salient feature of forensic nurses' accounts of their practice. The present study was carried out to determine the knowledge of staff nurses regarding the need of forensic nursing in emergency department.

The objective of the study was to To Assess The Knowledge Regarding The Need Of Forensic Nursing In Emergency Department Among The Staff Nurses In A Selected Hospital At Visakhapatnam ,Andhra Pradesh" The investigator obtained the permission from the, nursing superintendent of king George hospital, VISAKHAPATNAM.

The structured self administer knowledge questionnaire method was carried out for the data collection in order to assess the knowledge of staff nurses regarding forensic nursing. The data obtained were analyzed and interrupted in terms of the objective and assumptions based on the descriptive statistics.

\section{Major Finding Of The Study:}

Findings regarding demographic variables. The data was collected in the month of $15^{\text {th }}$ April to $14^{\text {th }}$ May 2011 from 60 samples. The data analysis and interpretation of data was done with the help of descriptive and inferential statistics.

That majority 39\% (23) of staff nurses were in the age group of $20-30$ years where as 38\% (22) were in the age group of 31-40 and only $23 \%(14)$ were in the age group of $41-50$ years.

In the area of knowledge majority $(53.3 \%)$ of staff nurses had inadequate knowledge, whereas ( $46.6 \%)$ had moderate knowledge and none of them had adequate knowledge on need of forensic nursing in emergency department. Which depicts strong need to create awareness among the expanded role. Since calculated value of chi- square is less than the tabulated value, then Ho is accepted at $0.05 \%$ of level of significance inferred that there is no association between level of knowledge and selected demographic variables. 
In the area distribution of knowledge with selected demographic variables there is no significant association since the chi-square of all the variables is less than the table value.

The findings of the study concluded that the incidence of level of knowledge of staff nurses regarding the forensic nursing is inadequate and also there is no statistical significant was established. The presence of this problem with high prevalence of inadequate knowledge can not be neglected. This motivated the investigator to develop a self instructional module on forensic nursing.

\section{NURSING IMPLICATION:}

The findings of the study have valuable implications towards nursing education, nursing research and nursing practices.

\section{Nursing Education:}

One of the leading function of the nursing is to educate. The scope of education is also increasing to meet the changing demand of the people in society. Nursing education plays a vital role in preparing the nurses for the well being of people in various areas. As the nursing is expanding its role day by day similarly forensic nursing is also a new trend in nursing. Therefore all the nursing students and nurse educators should aware about forensic nursing as their sub specialties and need. This study findings helps the nurse educator to update their knowledge and use the tool to guide student nurses. The nursing students and clinical instructor should have an update knowledge regarding the need of forensic nursing in order to preserve the evidences and help the victims in getting the justice.

\section{Nursing practice:}

Revolution in the era and its challenging need had great influence on health care delivery system and also on nursing practice aiding in expanding the role as forensic nursing. understanding the process of evidence collection and its preservation is one of the most important aspect of the forensic nurse. So every nurse should make use of these results to update their knowledge. The present study suggested that there is an increased need for conducting awareness preogramme for the staff nurses regarding forensic nursing. The nurses practice can plan for an inservice program and guide the team in preparing the health education material. As a nurse practitioner, nurses should make an effort to motivate .The other staff nurses to know about the need of forensic nursing in emergency department.

\section{Nursing Research:}

The essence of research is to build a body of knowledge in nursing to meet the emerging challenges in to deliver the health services to the people. to thrive as a profession, nursing must not only keep up with the pace, but set the pace for the future health care. Further the researcher can utilize these findings to solve their research problem.

Research is a process of refining again and again the obtained data or information. So the researcher on forensic nursing will provide new knowledge regarding it, as the technological and thinking level is going on changing. This researcher will help others to get influenced and it will make any other researchers to be notified among the nursing practice.

Limitations:

* This study was limited to descriptive approach.

* This study was restricted to be performed only in a selected hospital.

* A structured questionnaire constructed by the investigator was used to collect information on forensic nursing which was of restrictive responses.

\section{Recommendations For Further Studies:}

Based on the findings of the study, the following recommendations are made:

$>$ A similar study can be conducted at a large sample.

$>$ An observational study can be conducted to assess the practice of the staff nurses in evidence collection and preservation.

$>$ A comparative study can be conducted between Government Hospital staff nurses and Private Hospital staff nurses.

$>$ A similar study can be conducted with specific teaching staterges such as structured teaching programme regarding need of forensic nursing in emergency department.

This chapter has brought out the various implications of this study and also has provided suggestions for future studies.

\section{REFERENCES}

[1] Nursing As A Profession by Praveen Prakash, published: Monday August 17, 2009, http.//www.vims.ac.in

[2] Baxter, V. (2002). Nurses' perceptions of their role and skills in a medium secure unit. British Journal of Nursing. 11(20), 1312-1319.

[3] Forensic Exams in the Emergency Room A Guide for Victims of Sexual Assault,2009Rosa Underwood, Dec 6.

[4] Bathinda, Punjab, Garg V, Verma SK. J ,Profile of Medicolegal Cases at Adesh Institute of Medical Sciences and Research,. Ind. Acad. Forensic Med.; 32(2): 150-52,2010

[5] Gilson, J.A, Forensic nursing: A most competent practice. American Journal of nursing, 6 (3), 5-9,2000 .

[6] What Is a Forensic Clinical Nurse Specialist? By Steven Symes, eHow Contributor updated April 10, 2011. www.articledashboard.com/.../Isforensic-nursing...emerging-field-/438093

[7] Forensicnursing.blogzayo.com/ -

[8] Forensic Exams in the Emergency Room: A Guide for Victims of Sexual Assault | Suite101.com http://www.suite101.com/content/forensic-exams-inthe-emergency-room-a178146\#ixzz1PB5DN421

[9] http:Nwww.sane-sart.com/

[10] Lynch, V.A, Clinical Forensic Nursing: A Descriptive Study in Role Development, Arlington: University of Texas. Unpublished Thesis, 1990 .

[11] O'Brien CO. Sexual Assault: Clinical Issues; Light staining microscope: Clinical experience in a Sexual Assault Nurse Examiner (SANE) program. J Emerg Nurs, 24: 95 -97, 1998.

[12] Part 2. Inside Forensic Nursing: Forensic Nursing Roles, Posted: 04/15/2008 Medscape Nurses (C) 2008 Medscape.

[13] Harris, C; Sukhai, A. \& Matzopoulos, R. (2004). National fatal injury profile. Available at http://www.mrc.ac.za/crime/crime.htm [43 paragraphs] 2006/02/10.

[14] Lynch, Virginia A. MSN, RN, Forensic nursing in the emergency department: A new role for the ournals.lww.com , Home , November,Volume 14 - Issue, 1991. 
[15] Melton, S.M.; McGwia, G.; James, H. \& James, M, Motor vehicle crashed related mortality is also with pre-hospital and hospital based resources availability. Journal of Trauma, 2003 54(2), 273-280.

[16] Dada, A. \& McQuoid-Mason, D.J,Introduction to Medico legal Practice. 2nd ed.Durban: Butterworths, 2001.

[17] Lynch, V.A,The new detective's forensic nurses advance health and justice,2000. Available at: http://www.nurseweek.eom/ce/cel620@html. [20 paragraphs]. 2004/11/26

[18] Dr. Vishal Garg, Dr. S.K. Verma, Trends of Poisoning in Rural Area of South-West, Punjab, Journal of Indian Acad Forensic Med, 32(3) Dec 6, 2009Rosa Underwood

[19] Feature Article The Case for Forensic Nursing, http://www.minoritynurse.com.

[20] Forensic Nurse online forensicnursemag.com "Forensic Nursing: It Take Education” Donna Garbacz Bader, Ma, MSN, RN, D-ABMDI @ 2004 Virgo Publishing, Inc.

[21] Read more: What Is a Forensic Clinical Nurse Specialist? | eHow.com http://www.ehow.com/info_8194873_forensic-clinical-nursespecialist.html\#ixzz1PAzS7VHY

[22] Julia B.George. Nursing Theories- the base for professional nursing practice. 4th edition, Appleton and lunge, 118-35.

[23] Anne Marriner Tomey, Martha Raile Alligood Nursing Thoerist and their work, 6th Ed, Mosby publication, 2002, 232-50

[24] Nancy burns, susan k.Grove, understanding nursing research, building an evidence - based practice, 4th Ed, Saunders publications, 2007;236-38

[25] Singh Saurabh1, Sr. Resident, Kumar Parsaik Ajay, review International Journal of Medical Toxicology \& Legal Medicine Year : 2007, Volume : 10, Issue : 1

[26] Dr. Bharath Kumar Guntheti, Dr. Shaik Khaja, Dr. S.S. Panda, Original Research Paper A Study of Serum Cholinesterase Levels in Organo phosphorous Poisoning Case, review J Indian Acad Forensic Med, 32(4)

[27] A study at the Shock Trauma Center (Baltimore City, USA), Accident Analysis \& Prevention, Volume 33, Issue 6, November 2001, Pages 771-782

[28] O. Akdur, P. Durukan, S. Ozkan, L. Avsarogullari, O. Salt \& I. Ikizceli \{2008), Faculty of Medicine Department of Emergency Medicine, Kayseri, Turkey. e-mail: oakdur@hotmail.com

[29] Hassan Q, Bashir MZ, Mujahid M, Munawar AZ, Aslam M, Marri MZ, PubMed U.S. National Library of Medicine National Institutes of Health J Pak Med Assoc. 2007 Nov;57(11):539-42. Medico-legal assessment of sexual assault victims in Lahore.

[30] Carla Kmett Danielson, Melisa M Holmes, Adolescent sexual assault: an update of the literature. by Carla Kmett Danielson, Melisa M Holmes Volume: 16, Issue: 5, Pages: 383-388 PubMed ID: 15353946

[31] Tracey Williams, Sandra Richardson, Paul O'Donovan, Michael Ardagh (2005)"

[32] The forensic nurse practitioner role (emergency nursing)--potential response to changing health needs in New Zealand. by Tracey Williams, Sandra Richardson, Paul O'Donovan, Michael Ardagh Volume: 24, Issue: 1, Pages: 111-123PubMed ID: 15887617

[33] Graylands Hospital, Mt Claremont, Australia, An ethnographic study of nurses in a forensic psychiatric setting: education and training implications, Graylands Hospital, Mt Claremont, Austral, Aust N Z J Ment Health Nurs. 1995 Jun;4(2):77-82.

[34] Sitterding HA, Adera T, Shields-Fobbs E Contin (2003) Spouse/partner violence education as a predictor of screening practices among physicians. 2003 Winter;23(1):54-63.

[35] Garimella RN, Plichta SB, Houseman C, Garzon L(1998) MEDLINE Abstracts: Violence Against Women -- Professional Issues Related to Screening Acad Med. 2002;77(12 Pt 1):1262-1265
[36] Martin SL, Young SK, Billings DL, Bross CC. "A WEEK-IN-REVIEW FEATURED REPORT" Health care-based interventions for women who have experienced sexual violence: a review of the literature. Trauma Violence Abuse. 2007 Jan;8(1):3-18.

[37] Susan. Simpson "The relationship between psychiatric nurses' communication skills and patients' evaluations of their nursing care" http://content.lib.utah.edu/u?/us-etd2,154

[38] Nomusa N.T. Abdool, M Curationis (Critical Care \& Trauma Nursing), Petra Brysiewicz, M Curationis, $\mathrm{PhD}$, forensic nursing role in emergency department, Journal of Emergency Nursing Volume 35, Issue 1, January 2009, Pages 16-21

[39] Stacey B. Plichta, ScD; Paul T. Clements, PhD, APRN, BC, DF-IAFN; Clare Houseman, PhD, APRN, BC ( 2009, Models of Care for Sexual Violence Victims in the Emergency Department, hs.odu.edu/commhealth/resources/ENVH_Graduate_SelfStudy.pdf

[40] Ewers P, Bradshaw T, McGovern J, Ewers B (2002), Does training in psychosocial interventions reduce burnout rates in forensic nurses, Journal of Advanced Nursing Volume 37, Issue 5, pages 470-476, March 2002

[41] Karen S. Hayward, PhD, RN, SANE-A, with Christine Collaer-Muzzo, MA ,Starting a SANE/SART Program: Opportunities, Challenges and Rewards, www.zoominfo.com/people/Hayward_Karen_121743955.aspx

[42] Early MR, Williams RA (2002) conducted a study on Emergency Nurses' Experience With Violence, Journal of Emergency Nursing . 2002 Jun;28(3):199-204.

[43] Arlene Kent-Wilkinson (2009) "An exploratory study of forensic nursing education in North America, University of Saskatchewan Library Electronic Theses \& Dissertations, URN etd-08262008-171000

[44] H Carmel, M Hunter ,Staff injuries from inpatient violence ,Hospital community psychiatry (1989) Volume: 40, Issue: 1, Pages: 41-46 PubMed ID: 2912839

[45] M Rask, I R Hallberg ,Forensic psychiatric nursing care--nurses apprehension of their responsibility and work content, Journal of Psychiatric and Mental Health Nursing (2000) Volume: 7, Issue: 2, Pages: 163-177 PubMed ID: 11146912

[46] Kelli Eldredge, RN, CCRN, MSN Wellspan Health, York Hospital, York, PA $\{2007\}$,Assessment of trauma nurse knowledge related to forensic practice, Journal of Forensic Nursing Volume 4, Issue 4, pages 157-165, December 2008

[47] Janice Du Mont, EdD (Research Scientista) Deborah Parnis, PhD (Associate Professor ), the opinions and practices of nurse examiners and nurses are compared, Applied Nursing Research Volume 16, Issue 3, August 2003, Pages 173-183.

[48] Polit DE. Hungler B.P Nursing research principles and methods, 6th Ed, Philadelphia Lippincott company; 2005:107, 79,115-124,706-712.

[49] Nancy burns, Susan K. Grove, Understanding nursing research, building an evidence -based practice, 4th Ed, Saunders publication, 2007, 236-38.

[50] International Association of Forensic Nurses. About IAFN. [Web site]. 2002.http://www.iafn.org/about/default.html.

\section{AUTHORS}

First Author - S.V.L. PADMAKUMARI, MEDICAL SURGICAL NURSING, KATURI COLLEGE OF NURSING, GUNTUR. 


\section{SELF INSTRUCTION MODULE FOR STAFF NURSES ON FORENSIC NURSING}
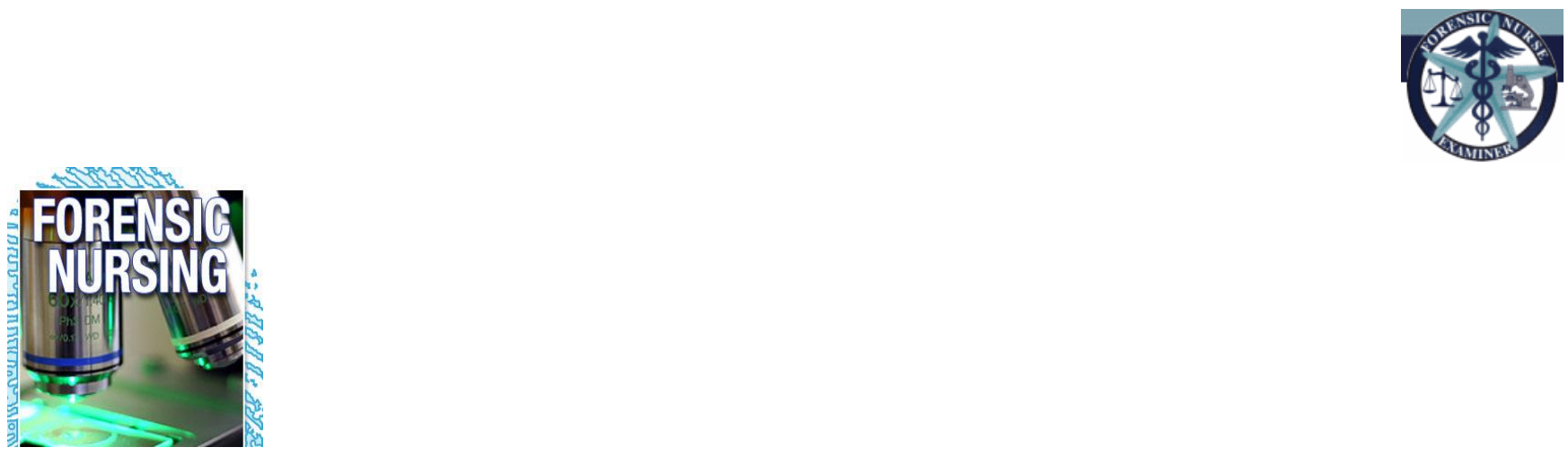

\section{PREFACE:}

Forensic Nursing is an exciting new career option for healthcare professionals and law enforcement officers. Forensic nursing is said to be the bridge between legal proceedings and health care. It involves working with law enforcement personnel to assist in the investigation of crimes. One of the most important roles of forensic nurses is to collect evidence from both the victims and suspects and treat the victims of the violent crimes for physical and emotional recovery. Their responsibilities also include testifying in court as a fact witness or as an expert witness. Fact witness is someone who saw and experienced the situation firsthand while an expert witness is someone who offers intelligent views and opinions about a certain situation.

\section{GENERAL OBJECTIVES OF SELF INSTRUCTIONAL MODULE}

After studying this module ,you will gain adequate knowledge regarding Forensic Nursing and its importance in emergency department and apply the knowledge in daily practical area.

\section{SPECIFIC OBJECTIVES:}

Know the history of Forensic Nursing

Define forensic nursing

List out the sub specialties of forensic nursing

Explore the importance of forensic nursing

Explain the role of forensic nurse

Identify the importance of forensic nursing in emergency department.

List out forensic nursing organizations.

\section{Guide Lines For The Use Of The Self- Instructional Module}

This SIM is a self contained learning package, which includes materials necessary to understand regarding the need of forensic nursing in emergency department.

It is important to go through the entire SIM in a systematic way. Take your own time to read this material carefully, understand and apply in your practical area.

After going through the entire SIM you are requested to take the test given at the end.

Compare your answer with the key provided. If all your answers are correct, your learning has been very effective.

In case some of the answers are wrong, refer to the page mentioned in the key for the specific answer in the content with the explanation.

History of Forensic Nursing 
Forensic Nursing is a relatively new field in nursing. The Term "Forensic Nursing" didn't even originate until the early 1990's. It was born out of a conference in St. Paul Minnesota in 1992 when a relatively small group of about 70 nurses got together for the first ever national convention of sexual assault nurses. It quickly became evident to the attendees about how much they had in common with each other and that many of them shared similar problems at their own centers.

\section{Forensic Nursing Defined}

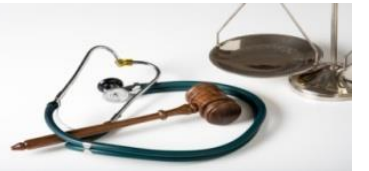

A Forensic nurse is a nurse with specialized training in forensic evidence collection, criminal procedures, legal testimony expertise. The Forensic nurse becomes that liaison between the medical profession and that of the criminal justice system. In Order to be certified as a forensic nurse, you must possess a active, valid, and unrestricted Nursing license in the state in which you intend to practice in.

\section{Sub Specialties of Forensic Nursing}

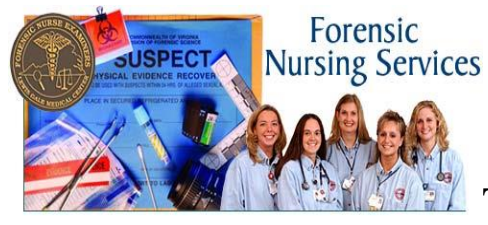

There are many different roles and specialties that a forensic nurse can try to specialize in. the following list is meant to give some helpful ideas of careers for forensic nursing, and should not be viewed as a complete list of nursing career choices.

\section{Correctional Nursing Specialists}

Correctional nursing specialists provide quality health care services such as attending to the sick, performing routine physical examinations and administering medication to persons in custody by the courts, including those who are in jail, juvenile offender facilities and other correctional institutions.

\section{Forensic Clinical Nurse Specialists}

Forensic clinical nurse specialists have an advanced forensic nursing degree and work as expert clinicians, teachers, researches, consultants and administrators in various forensic situations.

\section{Forensic Gerontology Specialists}

A forensic gerontology specialist assists in the investigation of abuse, neglect, or exploitation of the elderly. Though they may work in hospitals, they typically work in facilities that are focused to caring for the old like nursing homes.

\section{Forensic Nurse Investigators}

Forensic nurse investigators work with detectives to determine the exact cause of an unexpected or violent death. They are usually called to the crime scene to examine the body, take blood and tissue samples, arrange for the body to be taken to the morgue for autopsy, and collect evidence to help solve the crime.

\section{Forensic Psychiatric Nurses}

Forensic psychiatric nurses provide rehabilitative care to individuals - criminal offenders, criminal defendants, or even their own colleagues - who are suffering from emotional trauma from a harrowing experience.

\section{Legal Nurse Consultants}

Legal nurse consultants give advice to attorneys on court cases that involve medical issues. They facilitate communication and coordination between attorneys, physicians and clients and interpret medically-related information that is relevant to a case or claim.

\section{Nurse Coroners or Death Investigators}


Nurse coroners or death investigators use their nursing skills to analyze the scene of a suspicious death. They examine the body to estimate the time of death and look for evidences that might help them determine the cause.

\section{Sexual Assault Nurse Examiners}

Sexual assault nurse examiners provide emotional support and prompt medical care to survivors of sexual assault. They document the account of the assault, perform necessary medical exams to collect crucial evidence, and may even testify in court as expert witness. Their responsibilities also include giving referrals for the victim's sustained care.

Why is Forensic Nursing Important?

Victims of violence and abuse require care from a health professional who is trained to treat the trauma associated with the wrong that has been done to them-be it sexual assault, interpersonal violence, neglect, or other forms of intentional injury. Forensic nurses are also a critical resource for anti-violence efforts. They collect evidence and give testimony that can be used in a court of law to apprehend or prosecute perpetrators who commit violent and abusive acts.

By hiring and training Forensic Nurses, communities supply themselves with a vital link to the administration of justice. As Vice President Joseph Biden said in a commentary written in 2006, "Forensic Nurses play an integral role in bridging the gap between law and medicine. They should be in each and every emergency room".

\section{Roles of Forensic Nurses}

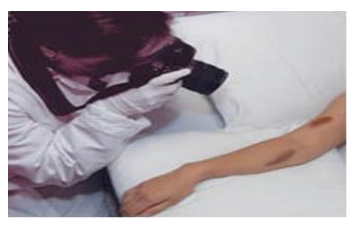

Forensic nursing is a combination of nursing science and legal issues. This is a growing new field that allows nurses to work with crime victims and investigate deaths.

\section{Collect Evidence}

While treating the their patients' wounds, forensic nurses collect vital evidence that is used to solve crimes. To do this, these nurses must be able to show their patients enough empathy to keep them calm while evidence is taken.

\section{Interpret Nonverbal Communication}

Many victims of crime are unable to talk about their ordeals, so it's the job of forensic nurses to decipher their patients' nonverbal communication. In addition, forensic nurses must be able to use medical histories and current injuries to ascertain the truth about what really happened to the patients.

\section{Investigate Deaths}

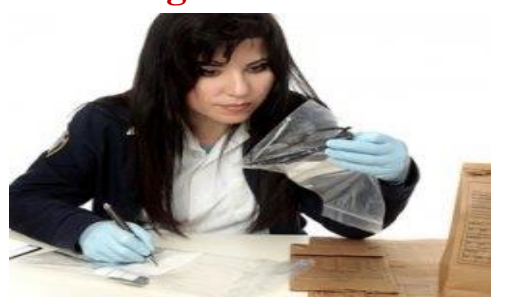

Forensic nurses who work in emergency rooms or intensive care units help to investigate deaths. They must know how to assist in examining a body and interpreting crime scenes and medical records.

\section{Work with Natural Disasters}


During natural disasters, forensic nurses assist patients with the emotional and physical effects of these traumatic experiences. This work includes trauma care, the detection of infectious disease and mental health services.

\section{Treating Victims of Violence}

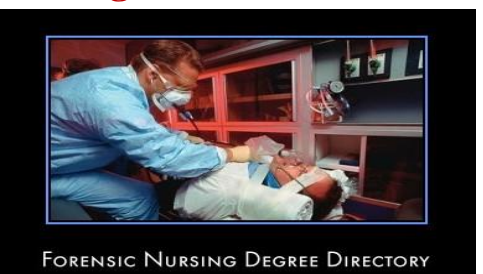

Forensic nurses that receive specialized training might work with patients who have been victims of interpersonal violence. When doing this, nurses will treat and support victims as well as help them get out of abusive relationships.

\section{Forensic nursing in emergency department:}

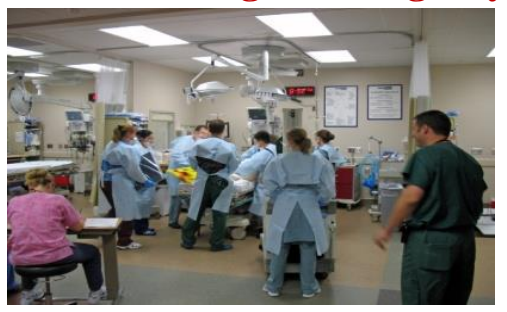

Forensic nursing is an emerging field that combines nursing skills with forensic science and criminal investigation. It's a new wing in the American judiciary system. Forensic nurses are trained to carry out clinical diagnosis, provide legal nurse consulting, help with criminal prosecution cases and provide medical aid to victims. A forensic nurse is the mediator between medical sciences and law enforcement. At present there are around 75000 forensic nurses in the US. Their need and demand is ever increasing.

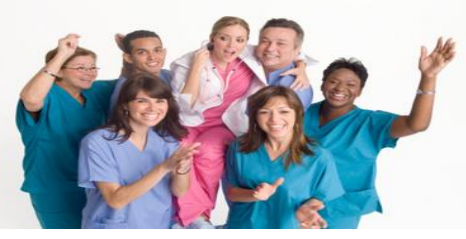

Forensic nursing has scope in various fields. Forensic nurses are first of all needed in the emergency room of a hospital. In the confusion and chaos of an emergency room often valuable evidence is lost. You never know if the critically injured patient was the victim of an accident or human violence. Many such victims of domestic violence or other criminal acts are admitted to a hospital where generally evidence against the criminal is overlooked and hence lost. The presence of a forensic nurse ensures that this does not happen. A Forensic nurse is fully trained to look into every aspect of the case and collect evidence. This way the criminal does not easily escape from the law. There is a desperate need to check the fast growing crime rates in our society which makes forensic nursing a necessity. So if working with the dead bothers you could choose other fields of specialization.

\section{SUMMARY:}

This self instruction module gives information on what is forensic nursing, its history and sub specialties. It also explained the role of forensic nurse and its importance in emergency department. Hope this module helped you to give adequate information about the need of forensic nursing in emergency department.

\section{REVIEW QUESTIONS:}

State whether the following statement are true or false:

This publication is licensed under Creative Commons Attribution CC BY.

http://dx.doi.org/10.29322/IJSRP.12.01.2022.p12128

WWW.ijsrp.org 
1) Forensic nursing involves working with law enforcement personal?

2) The term "Forensic Nursing" was originated in the year 1995 ?

3) Legal nurse consultant and sexual assault nurse examiner are the sub specialties of forensic nursing?

4) Forensic nurses are also a critical resources for antiviolence efforts?

5) Evidence collection and giving testimony is not the duty of the forensic nurse?

6) Forensic nurse should know how to investigate the death and interpret crime scens and medical records?

7) During documentation the forensic nurse should document any bruise colour if present?

8) Visual records are made after the treatment begins?

9) Patient cloths are crucial evidence for forensic investigation?

10) All belongs of the patient should be handed over to their relatives and patients? 


\section{HS}

\section{TVH}

\section{OI}

可

กעI

6
HS

TVH

8

百

กษI

\section{$L$ \\ 百}

กบI

9

HS

TVH

$\mathbf{S}$

可

กעు

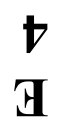

กעI

\section{$\mathcal{E}$ \\ HS}

TVH

KEY:

\section{$\tau$ \\ Нกบป \\ I}

\section{GLOSSARY:}

1. Forensic: used or applied in the investigation and establishment of facts or evidence in a court of law.

2. Liaison: connection; link; contact; conspiracy.

3. Harrowing: extremely painful

4. Residues: something left after other parts have been taken away.

5. Custody: Judicial or penal safe-keeping.

6. Jagged edge: having rough or sharp and uneven edges. 
7. Homicide: The killing of one person by another.

\section{REFERENCES}

Books:

1) Forensic Nurse: The New Role of the Nurse in Law Enforcement

2) Forensics For Dummies by Douglas P. Lyle

3) Forensic Nursing: Scope and Standards... by American Nurses Assoc.

4) Forensic Nursing: A Concise Manual by Donna M. Garbacz Bader

5) Forensic mental health nursing: current approaches Chris Chaloner, Michael Coffey - 1999

6) Forensic Nursing: A Handbook for Practice - Rita Hammer, Barbara Moynihan, Ph.D., Elaine M. Pagliaro 2009

7) Mental Health Nursing: An Evidence Based Introduction - Steven Pryjmachuk

8)F orensic nursing and mental disorder in clinical practice - Norman McClelland

Journals:

1) Journal of Forensic Nursing The Official Journal of the International Association of Forensic Nurses .

2) Criminalistics and the forensic nursing process Journal of Forensic Nursing - June 1, 2011 Ann Wolbert BurgessMichael J. PiatelliGeorgia Pasqualone.

3) Nonoccupational postexposure prophylaxis for human immunodeficiency virus in Sub-Saharan Africa: A systematic review Journal of Forensic Nursing - June 1, 2011 Authors: Kimberly A. LonswayJoanne Archambault.

4) Working under threat: Fear and nurse-patient interactions in a forensic psychiatric setting Journal of Forensic Nursing - June 1, 2011 Authors: Jean Daniel JacobDave Holmes.

5) Struggling to survive: The experiences of women sexually assaulted while intoxicated Journal of Forensic Nursing - June 1, 2011 Authors: Karen A. Kalmakis.

6

Article:

1) Burgess AW, Piatelli MJ, Pasqualone G Criminalistics and the forensic nursing process. [Journal Article] J Forensic Nurs 2011 Jun; 7(2):97-10

2) Draughon JE, Sheridan DJ Nonoccupational postexposure prophylaxis for human immunodeficiency virus in Sub-Saharan Africa: A systematic review. [Journal Article] JForensic Nurs 2011 Jun; 7(2):89-96.

3) Lonsway KA, Archambault J Reply to Article "Receiving a forensic medical exam without participating in the criminal justice process: What will it mean?". [Journal Article] J Forensic Nurs 2011 Jun; 7(2):78-88.

4) Jacob JD, Holmes D Working under threat: Fear and nurse-patient interactions in a forensic psychiatric setting. [Journal Article] J Forensic Nurs 2011 Jun; 7(2):68-77.

5) Kalmakis KA Struggling to survive: The experiences of women sexually assaulted while intoxicated. [Journal Article] J Forensic Nurs 2011 Jun; 7(2):60-7.

6) Peternelj-Taylor C Is impostor syndrome getting in the way of writing for the Journal of Forensic Nursing? [Editorial] J Forensic Nurs 2011 Jun; 7(2):57-9.

7) Omalu B Pathophysiological nervous system consequences of conducted electrical devices and sudden, unexpected death. [Journal Article] J Forensic Nurs 2011 Mar; 7(1):51-3.

8) Carr M Evidence collection beyond the 72-hour rule. [Letter] J Forensic Nurs 2011 Mar; 7(1):49.

9) Tenkanen H, Tiihonen J, Repo-Tiihonen E, et al. 
10) Interrelationship between core interventions and core competencies of forensic psychiatric nursing in Finland. [Journal Article] J Forensic Nurs 2011 Mar; 7(1):32-9.

11) Campbell R, Greeson M, Patterson D Defining the boundaries: How sexual assault nurse examiners (SANEs) balance patient care and law enforcement collaboration. [Journal Article] J Forensic Nurs 2011 Mar; 7(1):17-26

12) Rose DN, Peter E, Gallop R, et al. Respect in forensic psychiatric nurse-patient relationships: A practical compromise. [JOURNAL ARTICLE] J Forensic Nurs 2011 Mar; 7(1):3-16

13)Keller P, Lechner M Injuries to the cervix in sexual assault victims. [Journal Article] J 